\title{
PENGARUH STRATEGI PEMBELAJARAN DAN KEMAMPUAN BERPIKIR ABSTRAK TERHADAP HASIL BELAJAR MATEMATIKA
}

\author{
Lily Rohanita Hasibuan', Mukhtar ${ }^{2}$, Abdul Hamid, K. $^{3}$ \\ ${ }^{I}$ Sekolah Menengah Atas Negeri Rantau Prapat, Labuhan Batu, Sumatera Utara \\ ${ }^{2,3}$ Program Pascasarjana, Universitas Negeri Medan, Medan \\ Ililyrohanitahsb@gmail.com; ${ }^{2}$ mukhtar.dr.mt@gmail.com;3abdhamid_k@yahoo.com
}

\begin{abstract}
Abstrak: Penelitian ini bertujuan untuk mengetahui: (1) perbedaan hasil belajar matematika antara siswa yang diajar dengan strategi pembelajaran inkuiri dibandingkan dengan siswa yang diajar dengan strategi pembelajaran ekspositori; (2) perbedaan hasil belajar matematika antara siswa yang memiliki kemampuan berpikir abstrak tinggi dibandingkan dengan siswa yang memiliki kemampuan berpikir abstrak rendah; dan (3) interaksi antara strategi pembelajaran dengan kemampuan berpikir abstrak dalam mempengaruhi hasil belajar matematika. Metode penelitian yang digunakan adalah metode eksperimen. Hasil penelitian menunjukkan bahwa hasil belajar matematika siswa yang diajar dengan strategi pembelajaran inkuiri (rata-rata 80,23) lebih tinggi dibandingkan hasil belajar siswa yang diajar dengan strategi pembelajaran ekspositori (rata-rata 71,33); kemudian hasil belajar matematika siswa yang memiliki kemampuan berpikir abstrak tinggi (rata-rata 80,20) lebih tinggi dibandingkan dengan siswa yang memiliki kemampuan berpikir abstrak rendah (rata-rata 71,35). Selanjutnya penelitian menemukan bahwa tidak terdapat interaksi antara strategi pembelajaran dan kemampuan berpikir abstrak tehadap hasil belajar matematika siswa. Sebagai tindak lanjut dari hasil penelitian ini diharapkan kepada guru matematika untuk lebih inovatif dan kreatif dalam memilih strategi pembelajaran dan diharapkan untuk dapat menerapkan strategi pembelajaran inkuiri untuk meningkatkan hasil belajar matematika siswa.
\end{abstract}

Kata Kunci: Strategi Pembelajaran Inkuiri, Kemampuan Berpikir Abstrak, Hasil Belajar Matematika

\begin{abstract}
The objectives of this study to investigate: (1) the difference achievement of students on mathematics between the students who taught by Inquiry learning strategy and the students who taught by expository learning strategy; (2) the difference achievement of students on mathematics between students who have low and high abstract thinking ability; and (3) an interaction between learning strategy and abstract thinking ability toward the students' mathematics achievement. The research method used is experimental method. The result of experiment show that the students' mathematics achievement taught by inquiry learning strategy (80.22) is higher than the students taught by expository learning strategy (71.3), then the mathematics achievement of students with high abstract thinking ability (80.20) is higher than students with low abstract thinking ability (71.31). Then, the research also found that there is no interaction between learning strategy and abstract thinking ability toward the students' mathematics achievement. So, as the next step it implies the mathematics' teachers to be more innovative and creative in choosing the learning strategies and applies the inquiry learning strategy in increasing the students' mathematics achievement.
\end{abstract}

Keywords: Inquiry Learning Strategy, Abstract Thinking Ability, Students' Mathematics Achievement

\section{PENDAHULUAN}

Matematika merupakan suatu kerangka perkembangan ilmu pengetahuan dan teknologi bagi siswa. Dalam kehidupan sehari-hari, konsep dan prinsip matematika banyak digunakan dan diperlukan, baik sebagai alat bantu dalam penerapan-penerapan bidang ilmu lain maupun dalam pengembangan matematika itu sendiri. Masykur dan Fathani (2007) menyatakan matematika merupakan ilmu universal yang mendasari perkembangan teknologi modern, mempunyai peranan penting 
dalam berbagai disiplin, dan mengembangkan daya pikir manusia. Untuk menguasai dan menciptakan teknologi di masa depan, diperlukan penguasaan matematika yang kuat sejak dini. Hal ini dipertegas Uno (2009) matematika adalah sebagai suatu bidang ilmu yang merupakan alat pikir, berkomunikasi, alat untuk memecahkan berbagai persoalan praktis yang unsur-unsurnya logika dan intuisi, analisis dan konstruksi, generalitas dan individualitas, serta mempunyai cabang-cabang antara lain aritmatika, aljabar, geometi dan analitis. Dengan perkataan lain, matematika mempunyai peranan yang sangat esensial untuk ilmu lain yang utama sains dan teknologi.

Di dalam rumusan tujuan pembelajaran matematika diatas, melatih cara berpikir dan bernalar dalam menarik kesimpulan, misalnya melalui kegiatan penyelidikan, mengeksplorasi, eksprimen, menunjukkan kesamaan, perbedaan, konsisten dan inkonsisten. Karena itu pendidikan matematika harus mampu membekali siswa keterampilan yang dapat menjawab permasalahan mendatang. Berbagai daya dan upaya dalam meningkatkan kemampuan matematika siswa telah dilakukan oleh berbagai pihak. Namun hasilnya belum sesuai dengan tujuan yang diharapkan. Hal tersebut, sesuai dengan fakta dari Third Mathematics and Science Study (TIMMS), lembaga yang mengukur hasil pendidikan di dunia melaporkan bahwa kemampuan matematika siswa berada diurutan 34 dari 38 negara (Akbar dalam Turmudi, 2008).

Banyak faktor yang menjadi penyebab rendahnya kemampuan dan kurangnya pemahaman siswa, salah satu penyebabnya adalah strategi pembelajaran yang dilaksanakan oleh guru yang masih bersifat tradisional, yaitu siswa masih diperlukan sebagai objek belajar dan guru lebih dominan berperan dalam pembelajaran dengan memberikan konsep-konsep atau prosedurprosedur baku, sehingga pada pembelajaran ini hanya terjadi komunikasi satu arah. Siswa jarang diberi kesempatan untuk menemukan dan merekonstruksi konsep-konsep atau pengetahuan matematika secara formal, sehingga pemecahan masalah, penalaran dan komunikasi dianggap tidak terlalu penting. Hal ini, diperkuat lagi oleh pendapat Ratumanan (2004) bahwa siswa hampir tidak pernah dituntut mencoba strategi sendiri atau cara alternatif dalam memecahkan masalah, siswa pada umumnya duduk sepanjang waktu di atas kursi dan jarang siswa berinteraksi sesama siswa selama pelajaran berlangsung. Siswa cenderung pasif menerima pengetahuan tanpa ada kesempatan untuk mengolah sendiri pengetahuan yang diperoleh, aktifitas siswa seolah terprogram mengikuti algoritma yang dibuat guru.

Dalam rangka mengatasi hasil belajar Matematika yang masih relatif rendah dan belum memuaskan, maka berbagai upaya telah dilakukan untuk meningkatkan kemampuan hasil belajar siswa. Salah satu upaya yang dapat dilakukan untuk meningkatkan kualitas pembelajaran dengan penerapan strategi pembelajaran yang lebih baik. Kegiatan pembelajaran merupakan hal paling utama dalam pendidikan yang tidak terlepas dari peranan tenaga pengajar. Kemampuan tenaga pengajar menguasai teknologi pembelajaran untuk merencanakan, merancang, melaksanakan dan mengevaluasi serta melakukan feedback menjadi faktor penting guna mencapai tujuan pembelajaran. Kemampuan tenaga pengajar menguasai materi pembelajaran, gaya mengajar, penggunaan media, penentuan strategi dan pemilihan metode mengajar merupakan suatu usaha guna melancarkan proses pembelajaran dan meningkatkan hasil didalam pencapaian tujuan belajar (Hamalik, 2001).

Dengan demikian strategi pembelajaran merupakan suatu komponen yang sangat menentukan untuk terciptanya kondisi yang efisien dan efektif selama berlangsungnya kegiatan pembelajaran. Siswa dapat belajar dengan baik jika strategi pembelajaran diusahakan cepat, efisien dan efektif. Dikatakan efektif bila strategi pembelajaran tersebut menghasilkan hasil belajar sesuai dengan yang diharapkan atau dengan kata lain tujuan belajar tercapai. Dikatakan efisien bila strategi pembelajaran yang diterapkan relatif menggunakan tenaga, usaha, biaya dan waktu yang dipergunakan seminimal mungkin (Slameto: 1995).

\section{Hakikat Belajar dan Hasil Belajar Matematika}

Pada dasarnya matematika diperlukan oleh semua keilmuan untuk meningkatkan daya prediksi dan kontrol dari ilmu tersebut (Suriasumantri, 1995). Pembelajaran matematika bermanfaat dalam menata nalar, membentuk sikap peserta didik dan menumbuhkan kemampuan menggunakan/ 
menerapkan matematika. Hal ini berarti bahwa dalam proses pembelajaran tidak cukup jika hanya ditekankan pada keterampilan menghitung dan menyelesaikan soal saja tetapi juga berfungsi mengembangkan daya nalar melalui kegiatan penyelidikan, eksplorasi, eksperimen sebagai alat pemecahan masalah, pola pikir, dan model matematika serta sebagai alat komunikasi melalui simbol, tabel, grafik, diagram dalam menjelaskan gagasan.

Gredler (2011) mengemukakan bahwa belajar memecahkan soal menurut siswa untuk mengenal situasi yang disajikan dan menerapkan beberapa pengerjaan soal secara benar dan dengan urutan yang benar pula. Dalam konteks ini, objek matematika yang dipelajari adalah yang berkaitan dengan kemampuan peserta didik dalam menguasai fakta, keterampilan, konsep dan prinsip. Joyce and Weil (1992) menyatakan bahwa pengetahuan logika ditekankan dengan matematika dan logika. Hal ini dibangun oleh proses refleksi dan abstraksi. Peran pendidik dalam pengetahuan logika adalah mengarahkan peserta didik untuk membangun ilmu pengetahuannya sendiri melalui pertanyaan dan percobaan.

Menurut Suriasumantri (1995) matematika tidak hanya berhubungan dengan bilangan-bilangan serta operasi-operasinya, melainkan juga unsur ruang sebagai sasarannya. Menurut Higgins yang dikemukakan Depdiknas (2004) matematika adalah ilmu yang mempelajari konsep, simbol, serta hubungan antara konsep dan simbol tersebut. Objek matematika berupa fakta, konsep, prinsip, dan operasi yang abstrak sehingga dalam belajar matematika diperlukan berbagai kegiatan psikologis seperti melakukan abstraksi, klasifikasi, dan generalisasi.

Untuk merefleksi konsep, simbol, fakta, operasi dan prinsip matematika tersebut tentunya tidak terlepas dari suatu kegiatan yang sangat urgen, yaitu belajar. Belajar adalah suatu proses aktivitas yang dapat membawa perubahan pada individu (Roestiyah, 1995). Menurut Surjadi (1989) menyatakan perubahan yang terjadi antara lain: (1) penambahan informasi, (2) pengembangan atau peningkatan pengertian, (3) penerimaan sikap-sikap baru, (4) perolehan penghargaan baru, dan (5) pngerjaan sesuatu dengan menggunakan apa yang telah dipelajari. Hilgard yang ditulis Nasution (1995) mendefenisikan belajar sebagai proses yang melahirkan atau mengubah suatu kegiatan melalui latihan yang dibedakan dari perubahanperubahan oleh faktor-faktor yang tidak termasuk latihan. Sedangkan Dimyati \& Mudjiono(2006) mengungkapkan bahwa belajar adalah suatu proses perubahan tingkah laku individu melalui interaksi dengan lingkungan.

Belajar merupakan proses atau kegiatan yang dijalani secara sadar untuk mendapatkan perubahan, baik dalam bentuk pengetahuan, keterampilan dan sikap. Gredler (2011), mendefinisikan belajar sebagai seperangkat proses kognitif yang mengubah sikap stimulasi dari lingkungan menjadi beberapa tahapan pengolahan informasi yang diperlukan untuk memperoleh kapabilitas yang baru.. Dari berbagai pendapat tersebut diatas, dapat disimpulkan yang dimaksud dengan belajar adalah: (1) Aktivitas menghasilkan perubahan pada diri individu yang belajar, (2) Perubahan itu pada pokoknya adalah didapatnya kemampuan baru yang menetap dalam waktu yang relatif lama, baik sikap, pengetahuan, dan keterampilan, (3) Perubahan yang terjadi adalah karena usaha, artinya individu yang belajar menjalani latihan atau pengalaman tertentu. Prestasi belajar pserta didik dapat dilihat dari hasil belajarnya setelah melalui proses penilaian.

Hasil belajar adalah tingkat penguasaan suatu pengetahuan yang dicapai oleh peserta didik dalam mengikuti program pembelajaran sesuai dengan tujuan pendidikan yang ditetapkan. Sementara itu, Reigeluth (1983) berpendapat bahwa hasil belajar dirumuskan sebagai perilaku yang dapat diamati dan dapat menunjukkan kemampuan seseorang. Dari beberapa pendapat diatas dapat disimpulkan bahwa hasil belajar adalah kemampuan-kemampuan yang dimiliki peserta didik setelah ia menerima pengalaman belajarnya dan segala sesuatu yang diperoleh siswa melalui proses pembelajaran yang ditandai dengan adanya perubahan tingkah laku baik itu aspek pengetahuan, sikap maupun keterampilannya. Berkaitan dengan jenis-jenis kemampuan yang merupakan produk hasil belajar, Gagne seperti yang dikutip Gredler (2011) mengklasifikasikan hasil belajar menjadi lima macam yaitu: (1) keterampilan intelektual yang mencakup diskriminasi, konsep, prinsip, dan pemecahan masalah, semuanya diperoleh melalui materi pelajaran, (2) strategi kognitif yaitu kemampuan untuk memecahkan masalah dengan jalan mengatur proses internal masingmasing individu dalam memperhatikan belajar, 
mengingat, dan berpikir, (3) informasi verbal yaitu kemampuan untuk mendeksripsikan sesuatu dengan kata-kata, dengan jalan mengatur informasi-informasi yang relevan, (4) keterampilan motorik yaitu kemampuan untuk melaksanakan dan mengkordinir gerakangerakan yang berhubungan dengan otot, dan (5) sikap yaitu kemampuan internal yang mempengaruhi tingkah laku seseorang dan didasari oleh emosi, kepercayaan, serta faktor intelektual. Dengan demikian hasil belajar harus menggambarkan kelima kapabilitas tersebut.

Kategori kognitif Bloom yang dikutip oleh Anderson (2001) bahwa pengorganisasian taxonomi diklasifikasikan atas 6 kelas utama yaitu: (1) hasil belajar tingkat pengetahuan adalah kemampuan dalam mengingat, menyebutkan kembali, atau mengulang kembali informasi-informasi dengan lebih cepat, (2) hasil belajar tingkat pemahaman adalah kemampuan untuk menginterpretasi, menjabarkan atau mengemukakan kembali informasi, (3) hasil belajar tingkat penerapan adalah kemampuan menerapkan informasi, teori-teori, prinsip-prinsip, atau hukum-hukum ke dalam situasi baru, (4) hasil belajar tingkat analisis adalah kemampuan membuat perbandingan antara konsep-konsep tertentu dalam suatu analisa yang kritis untuk mengahsilkan pengetahuan baru, (5) hasil belajar pada tingkat sintesis adalah kemampuan membuat kesimpulan-kesimpulan tertentu berdasarkan teori yang telah dikemukakan, dan (6) hasil belajar pada tingkat evaluasi adalah kemampuan melakukan pengukuran dan penilaian. Berdasarkan kategori yang dikemukakan Gagne \& Briggs dan kategori kognitif Bloom dapat dilihat bahwa tiga dari lima kategori yaitu keterampilan intelektual, strategi kognitif, dan kemampuan verbal dapat disejajarkan dengan ranah kognitif Bloom.

Merril, seperti dinyatakan Reigeluth (1983) merincikan hasil belajar yaitu: mengingat, mengaplikasikan, dan menemukan segi isi pelajaran meliputi: fakta, konsep, prosedur, dan prinsip. Menurut Uno (2009), hasil belajar matematika merupakan hasil kegiatan dari belajar matematika dalam bentuk pengetahuan sebagai akibat dari perlakuan atau pembelajaran yang dilakukan siswa. Dalam bentuk pengetahuan meliputi fakta, konsep, prosedur, dan perinsip sebagai kajian matematika. Fakta merupakan pengetahuan tentang objek nyata, asosiasi dari kenyataan dan informasi verbal dari suatu objek, peristiwa atau manusia. Konsep merupakan pengetahuan tentang seperangkat objek konkrit atau defenisi. Prosedur merupakan pengetahuan tentang tindakan demi tindakan yang bersifat linear dalam mencapai suatu tujuan. Prinsip merupakan pernyataan mengenai hubungan dari dua konsep atau lebih. Konsep, prosedur dan prinsip matematika akan berarti atau bermakna bagi peserta didik bila dihubungkan dengan fakta yang ada dalam kehidupan sehari-hari. Sedangkan bentuk keterampilan yang menggambarkan tingkat kemampuan kognitif adalah keterampilan kognitif, yaitu keterampilan peserta didik menggunakan pikiran guna menghadapi suatu seperti pemecahan masalah dan pengambilan keputusan. Dalam hal ini Gagne and Briggs (1979) menyebutnya dengan istilah keterampilan intelektual dan strategi kognitif. Sedangkan sasaran olah pikir matematika untuk mencapai target hasil belajar memuat taksonomi Bloom adalah pencapaian ranah kognitif.

\section{Hakikat Strategi Pembelajaran}

Strategi memberikan tuntutan secara sederhana untuk menyampaikan mata pelajaran untuk menentukan kegiatan pembelajaran dan membantu siswa dalam mencapai tujuan belajar sehingga siswa dapat belajar lebih mudah dan lebih efektif. Secara umum strategi dapat diartikan sebagai suatu garis-garis besar haluan untuk bertindak dalam rangka mencapai sasaran yang telah ditentukan dikaitkan dengan pembelajaran. Strategi pembelajaran merupakan pola kegiatan guru dan siswa didalam proses pembelajaran yang menitikberatkan kepada keaktifan siswa guna mencapai perubahanperubahan sesuai dengan yang ditetapkan. Strategi berhubungan dengan cara penyampaian pesan dalam pembelajaran. Strategi harus memperhitungkan tujuan yang telah ditetapkan dan mempertimbangkan karakteristik siswa.

Dalam dunia pendidikan strategi diartikan sebagai a plan, method, or series of activities disigned to achieves a particular educational goa (David, 1976). Jadi, dengan demikian strategi pembelajaran dapat diartikan sebagai perencanaan yang berisi tentang rangkaian kegiatan yang didesain untuk mencapai tujuan pendidikan tertentu.

Menurut Kemp seperti yang dikutip oleh Sanjaya (2008) menjelaskan bahwa strategi pembelajaran adalah suatu kegiatan pembelajaran yang harus dikerjakan guru dan 
siswa agar tujuan pembelajaran dapat dicapai secara efektif dan efisien. Senada dengan pendapat di atas, Dick and Carey (2015) menyebutkan bahwa strategi pembelajaran itu terdiri atas seluruh komponen materi pembelajaran prosedur atau tahapan kegiatan belajar yang digunakan guru dalam rangka membantu siswa mencapai tujuan pembelajaran tertentu. Sanjaya (2008) memaparkan tentang bagaimana suatu proses pembelajaran berhasil mencapai tujuan yang merupakan hasil interaksi dan interelasi komponen-komponen yang membentuk sistem pembelajaran. Komponenkomponen tersebut adalah tujuan, materi pelajaran, strategi pembelajaran, media dan evaluasi. Setiap komponen akan mempengaruhi keberhasilan proses pembelajaran dan akan mempengaruhi keberhasilan pencapaian tujuan pembelajaran. Salah satu komponen tersebut adalah strategi pembelajaran.

Bagaimana

upaya mengimplementasikan rencana yang sudah disusun dalam kegiatan nyata agar tujuan yang telah disusun tercapai secara optimal, ini yang dinamakan dengan metode. Ini berarti, metode digunakan untuk merealisasikan strategi yang telah ditetapkan. Dengan demikian, bisa terjadi satu strategi pembelajaran digunakan beberapa metode. Misalnya, untuk melaksanakan inkuiri bisa digunakan metode tanya jawab atau bahkan diskusi dengan memanfaatkan sumber daya yang tersedia termasuk menggunakan media pembelajaran. Oleh karenanya, strategi berbeda dengan metode. Strategi menunjuk pada sebuah perencanaan untuk mencapai sesuatu, sedangkan metode adalah cara yang dapat digunakan untuk melaksanakan strategi. Istilah lain yang juga memiliki kemiripan dengan strategi adalah pendekatan. Pendekatan dapat diartikan sebagai titik tolak atau sudut pandang kita terhadap proses pembelajaran. Romizowaki (1981) berpendapat bahwa strategi pembelajaran merupakan suatu pendekatan menyeluruh yang dapat dibedakan menjadi dua strategi dasar yaitu penjelasan dan penemuan.

\section{Strategi Pembelajaran Inkuiri}

Pada dasarnya inkuiri dan diskoveri saling terkait antara satu sama lain. Inkuiri dalam bahasa Inggris inqury, berarti mempertanyakan, pemeriksaan atau penyelidikan. Sedangkan diskoveri artinya penemuan. Dengan melakukan penyelidikan, siswa akhirnya dapat memperoleh suatu penemuan. Strategi ini berkembang dari ide
John Dewey yang terkenal dengan "Problem solving method" atau metode pemecahan masalah. Langkah dalam pemecahan masalah merupakan suatu pendekatan yang dipandang cukup ilmiah dalam melakukan penyelidikan dalam rangka memperoleh suatu penemuan. Belajar dengan strategi inkuiri tidak terlepas dari teori konstruktivisme yang menyatakan bahwa siswa harus menemukan sendiri dan mentransformasikan informasi kompleks. Mengecek informasi baru dengan aturan-aturan lama dan merevisinya apabila aturan-aturan itu tidak lagi sesuai. Siswa yang benar-benar memahami dan dapat menerapkan pengetahuan, harus mampu memecahkan masalah, menemukan segala sesuatu untuk dirinya, dan berusaha untuk memunculkan ide-ide. Menurut Slavin (1995) teori konsruktivisme berkembang dari kerja Piaget, Vygotsky, teori pemerosesan informasi, dan teori psikologi kognitif yang lain seperti Bruner.

Ide-ide dari konsep strategi pembelajaran inkuiri (inquiry learning) banyak berlandaskan pada teori pembelajaran penemuan Jerome Bruner. Menurut Bruner seperti yang dikutip Sagala (2009) menganggap bahwa belajar penemuan sesuai dengan pencarian pengetahuan secara aktif oleh manusia, dan dengan sendirinya memberi hasil yang paling baik. Berusaha sendiri untuk mencari pemecahan masalah serta pengetahuan yang menyertainya, menghasilkan pengetahuan yang benar-benar bermakna. Bruner (1960) menyarankan agar siswa-siswa hendaknya belajar melalui partisipasi aktif dengan konsepkonsep dan prinsp-prinsip agar mereka dianjurkan untuk memperoleh pengalaman dan melakukan eksprimen-eksprimen yang mengizinkan mereka untuk menemukan prinsip-prinsip itu sendiri. Strategi pembelajaran inkuiri berarti suatu rangkaian kegiatan belajar yang melibatkan secara maksimal seluruh kemampuan siswa untuk mencari dan menyelidiki secara sistematis, kritis, logis, analistis, sehingga siswa dapat merumuskan sendiri penemuannya dengan percaya diri (Gulo, 2008).

Pembelajaran berbasis inkuiri merupakan pembelajaran yang berpusat pada siswa. Tujuan utama pembelajaran inkuiri adalah mendorong siswa untuk dapat mengembangkan disiplin intelektual dan keterampilan berfikir dengan memberikan pertanyaan-pertanyaan. Dick and Carey (2005) menyatakan bahwa strategi pembelajaran 
merupakan komponen-komponen umum dari suatu set bahan pembelajaran dan prosedurprosedur yang akan digunakan untuk mencapai hasil belajar tertentu siswa. Strategi pembelajaran inkuiri lebih menekankan kepada proses mencari dan menemukan.

Menurut Callahan yang dipaparkan oleh Amri \& Ahmadi (2010) menyatakan pembelajaran inkuiri mengacu pada pembelajaran melalui pengalaman yang memiliki karakteristik sebagai berikut: (1) mengidentifikasi masalah. Di sini orang melakukan sesuatu lalu melihat efeknya. Efek ini dapat saja berfungsi sebagi ganjaran atau hanya sekedar memberikan informasi mengenai hubungan kausalitas, (2) pengambilan keputusan tentang teknik pemecahan masalah. Hal ini berarti orang tersebut telah belajar konstruksi dari tindakannya, dan oleh karena itu telah belajar bagaimana berbuat untuk mencapai tujuannya dalam kasus tersebut, (3) mengidentifikasi solusi tentatif terhadap masalah yaitu dari contoh kasus kepemahaman mengenai kaidah umum yang berlaku terhadap kasus-kasus dimaksud. Ini mungkin pengkajian sejumlah contoh sebelum dapat melihat secara jelas adanya kaidah ini.

Strategi pembelajaran inkuiri adalah strategi pembelajaran yang menekankan pada rangkaian kegiatan pembelajaran yang menekankan pada proses berpikir secara kritis dan analitis untuk mencari dan menemukan sendiri jawaban dari suatu masalah yang dipertanyakan. Proses berpikir itu sendiri biasanya dilakukan melalui tanya jawab antara guru dan siswa. Strategi pembelajaran ini sering juga dinamakan heuristic, yang berasal dari bahasa Yunani yaitu heuriskein yang berarti saya menemukan (Sanjaya, 2008). Ada beberapa hal yang menjadi ciri utama strategi pembelajaran inkuiri. Pertama, strategi inkuiri menekankan kepada aktivitas siswa secara maksimal untuk mencari dan menemukan, artinya strategi inkuiri menempatkan siswa sebagai subjek belajar. Dalam proses pembelajaran, siswa tidak hanya berperan sebagai penerima pembelajaran melalui penjelasan guru secara verbal, tetapi mereka berperan untuk menemukan sendiri inti dari materi pelajaran itu sendiri. Kedua, seluruh aktivitas yang dilakukan siswa diarahkan untuk mencari dan menemukan jawaban sendiri dari sesuatu yang dipertanyakan, sehingga diharapkan dapat menumbuhkan sikap percaya diri (self belief). Dengan demikian, strategi pembelajaran inkuiri menempatkan guru sebagai sumber belajar, akan tetapi sebagai fasilitator dan motivator belajar siswa (Sanjaya, 2008).

Suyanti (2010) mengemukakan bahwa dalam penggunaan strategi pembelajaran inkuri terdapat beberapa prinsip yang harus diperhatikan oleh setiap guru yaitu: a) berorientasi pada pengembangan intelektual, tujuan utama dari strategi inkuiri adalah pengembangan kemampuan berpikir. Dengan demikian, strategi pembelajaran ini selain berorientasi kepaa hasil belajar juga berorientasi pada proses belajar. Karena itu, kriteria keberhasilan dari proses pembelajaran dengan menggunakan strategi inkuiri bukan ditentukan oleh sejauh mana siswa dapat menguasai materi pelajaran, akan tetapi sejauh mana siswa beraktivitas mencari dan menemukan sesuatu, b) Prinsip Interaksi, proses pembelajaran pada dasarnya adalah proses interaksi, baik interaksi antara siswa maupun interaksi siswa dengan guru, bahkan interaksi antara siswa dengan lingkungan. Pembelajaran sebagai proses interaksi berarti menempatkan guru bukan sebagai sumber belajar, tetapi sebagai pengatur lingkungan atau pengatur interaksi itu sendiri. Guru perlu mengarahkan (directing) agar siswa bisa mengembangkan kemampuan berpikirnya melalui interaksi mereka. Kemampuan guru untuk mengatur interaksi memang bukan pekerjaan yang mudah. Sering guru terjebak oleh kondisi yang tidak tepat mengenai proses interaksi itu sendiri, c) Prinsip bertanya, peran guru yang harus dilakukan dalam menggunakan strategi pembelajaran inkuiri adalah sebagai penanya. Sebab, kemampuan siswa untuk menjawab setiap pertanyaan pada dasarnya sudah merupakan sebagian dari proses berpikir, d) Prinsip Belajar untuk berpikir, belajar bukan hanya mengingat jumlah fakta, akan tetapi belajar adalah proses berpikir (learning how to think), yakni proses mengembangkan potensi seluruh otak baik otak kiri maupun otak kanan, baik otak limbik maupun otak neokortek. Belajar yang hanya cenderung memanfaatkan otak kiri, misalnya dengan memaksa anak untuk berpikir logis an rasional, akan membuat anak dalam posisi "kering dan hampa". Oleh karena itu, belajar berpikir logis dan rasional perlu didukung oleh pergerakan otak kanan, misalnya dengan memasukkan insur-unsur yang dapat mempengaruhi emosi, yaitu unsur estetika melalui proses belajar yang menyenangkan dan 
menggairahkan, e) Proses Keterbukaan, belajar adalah suatu proses mencoba berbagai kemungkinan bisa saja terjadi. Untuk itu siswa hendaknya diberikan kebebasan untuk mencoba sesuatu sesuai dengan perkembangan kemampuan logika dan nalarnya. Pembelajaran yang bermakna adalah pembelajaran yang menyediakan berbagai kemungkinan sebagai hipotesis yang harus dibuktikan kebenarannya. Tugas guru adalah menyediakan ruang untuk mengembangkan hipotesis dan secara terbuka membuktikan kebenaran hipotesis yang diajukannya.

Amri dan Ahmadi (2010) mengemukakan bahwa dalam pembelajaran yang berbasis inkuiri, strategi pembelajaran inkuiri memiliki prosedur sebagai berikut: (1) memberikan kesempatan untuk berbuat dan mengamati konsekuensi dari pekerjaan tersebut, (2) memeriksa pengertian siswa mengenai hubungan kausalitas yang terlihat dalam pekerjaan tersebut melalui pertanyaanpertanyaan ataupun dengan mengamati reaksi mereka, (3) memeriksa apakah telah dapat ditangkap atau dipahami oleh mereka tentang adanya kaidah umum yang mendasari kasuskasus yang diberikan dengan mengajukan pertanyaan-pertanyaan atau dengan mengamati kegiatan mereka sampai mereka memahaminya, dan (4) memberikan kesempatan untuk mengaplikasikan pengetahuan yang baru saja dipelajari terhadap situasi serta masalah riil.

\section{Strategi Pembelajaran Ekspositori}

Menurut Sanjaya

pembelajaran ekspositori adalah pembelajaran yang menekankan kepada proses penyampaian materi secara verbal dari seorang guru kepada sekelompok siswa dengan maksud agar siswa dapat menguasai materi pelajaran secara optimal. Pada strategi pembelajaran ekspositori, siswa belajar dengan mendengarkan penjelasan guru di depan kelas dan melaksanakan tugas jika guru memberikan latihan soal-soal kepada siswa tersebut. Semua anak dinilai sama tanpa membedakan siswa yang berintelegensi tinggi dengan siswa yang cepat atau pandai atau yang siswa kurang pandai seolah-olah dipaksakan untuk berjalan cepat seiring dengan temannya yang pandai.

Menurut Majid (2005) strategi pembelajaran ekspositori lebih berorientasi masukan, yaitu materi apa yang harus disampaikan kepada siswa sebagai tuntutan kurikulum (pencapaian target kurikulum).
Menurut Killen yang dikutip oleh Sanjaya (2008) menamakan strategi ekspositori ini dengan istilah strategi pembelajaran langsung (direct instruction), karena dalam strategi ini materi pelajaran disampaikan langsung guru, siswa tidak dituntut untuk menemukan materi itu. Siswa tidak dituntut untuk menemukan materi itu. Strategi pembelajaran ekspositori menekankan kepada proses bertutur, materi pelajaran sengaja diberikan secara langsung.

Asumsi yang mendasari penerapan strategi pembelajaran ekspositori (Lie, 2004) dapat dikategorikan menjadi empat yaitu: (1) proses pembelajaran merupakan usaha memindahkan pengetahuan guru ke siswa (tugas seorang guru adalah menerima, guru memberikan informasi dan mengharapkan siswa untuk mengahapal dan mengingatnya) (2) siswa dianggap botol kosong yang siap diisi dengan pengetahuan (siswa adalah penerima pengetahuan pasif, guru memiliki pengetahuan yang nantinya dihafal oleh siswa), (3) mengotak-ngotakkan siswa (guru mengelompokkan siswa berdasarkan nilai dan masukan siswa dalam kategori pengelompokkan yang homogen, siapa yang layak mengikuti unggulan dan siapa yang tidak layak), (4) memacu siswa dalam kompetisi (siswa bekerja keras untuk mengalahkan teman sekelasnya, siapa yang kuat, dia yang yang menang, orang tuapun saling bersaing menyombongkan anaknya masing-masing dan menonjolkan prestasi anaknya bagaikan memamerkan ayam aduan).

$$
\text { Dalam penggunaan strategi }
$$
pembelajaran ekspositori terdapat beberapa prinsip yang harus diperhatikan (Sanjaya, 2008) antara lain: (1) berorientasi pada tujuan, (2) proses pembelajaran menggunakan prinsip komunikasi, (3) prinsip kesiapan, (4) prinsip berkelanjutan. Langkah-langkah penerapan strategi ekspositori tersebut dapat diuraikan sebagai berikut: (1) Persiapan (Preparation), mempersiapkan siswa untuk menerima pelajaran antara lain mengajak siswa keluar dari kondisi mental yang pasif, membangkitkan motivasi dan minat siswa untuk belajar, merangsang dan menggugah rasa ingin tau siswa, menciptakan suasana dan iklim pembelajaran yang terbuka. (2) Penyajian (Presentation) yaitu langkah penyampaian materi pembelajaran sesuai dengan persiapan yang telah dilakukan. Ada beberapa hal yang harus diperhatikan dalam penyajian yaitu: penggunaan bahasa, intonasi suara dan menjaga 
kontak mata dengan dengan siswa dan menggunakan humor yang menyegarkan. (3) Korelasi (Correlation) yaitu menghubungkan materi pembelajaran dengan pengalaman siswa atau dengan hal-hal lain yang memungkinkan siswa dapat menangkap keterkaitannya dalam struktur pengetahuan yang telah dimilikinya terhadap materi pelajaran, baik makna untuk memperbaiki struktur pengetahuan yang telah dimilikinya, maupun makna untuk meningkatkan kualitas kemampuan berpikir, (4) Menyimpulkan (Generalization) adalah tahapan memahami inti (core) dari materi pembelajaran yang telah disajikan. Menyimpulkan dapat dilakukan dengan cara mengulang kembali inti materi, memberikan beberapa pertanyaan yang relevan dengan materi yang telah disajikan dan mengingat kembali keseluruhan materi pelajaran yang telah dibahas dan (5) Mengaplikasikan (Applikation) adalah kemampuan siswa setelah mereka menyimak penjelasan guru. Melalui langkah ini guru dapat menyimpulkan informasi tentang penguasaan dan pemahaman materi yang telah disajikan.

\section{Hakikat Kemampuan Berpikir Abstrak}

Frankel (dalam Patmonodewo, 2001) mendefinisikan berpikir sebagai pembentukan ide-ide, reorganisasi dan pengalamanpengalaman seseorang dan pengorganisasian informasi-informasi kedalam bentuk yang khas. Dari pendapat diatas diambil suatu kesimpulan bahwa komponen dasar yang perlu dalam berpikir adalah persepsi, mengingat, membandingkan, mengkategorisasikan dan penyimpulan.

Berpikir abstrak merupakan salah satu jenis kemampuan yang merupakan atribut inteligensi. Menurut Anastasi (1997) bahwa intelegensi "abstrak" merupakan tes-tes "bakat khusus" yang disusun untuk mengukur sebuah kombinasi tertentu dari bakat khusus seperti kemampuan verbal dan numerik. Intelegensi adalah ekspresi dari tingkat kemampuan individu pada saat tertentu dalam hubungan dengan norma usia tertentu yang ada. Tes-tes intelegensi yang dirancang untuk anak-anak usia sekolah atau orang dewasa adalah kemampuan-kemampuan verbal; untuk kadar lebih rendah, tes-tes ini mencakup kemampuankemampuan untuk simbol numerik dan simbolsimbol abstrak lainnya dominan dipakai dalam proses belajar disekolah.

Menurut Freeman yang dikutip oleh Nugroho (2004) membedakan defenisi tentang intelegensi atas: (1) kemampuan adaptasi, yaitu kemampuan yang menekankan kepada kemampuan penyesuaian diri seorang individu terhadap lingkungannya. Seorang dikatakan memiliki kemampuan adaptasi apabila ia tidak mengalami kesulitan dalam menyesuaikan diri dengan lingkungannya, melakukan penyesuaian dengan cara efektif, serta dapat mengubah tingkah lakunya sesuai dengan situasi yang dihadapi, (2) kemampuan belajar, memberikan tekanan pada pentingnya kemampuan belajar individu. Kemampuan belajar adalah suatu indeks dari intelegensi seseorang, (3) kemampuan berpikir abstrak, aspek yang ditekankan dalam kemampuan berpikir abstrak adalah penggunaan efektif dari konsep-konsep serta simbol-simbol dalam menghadapi berbagai situasi khusus dalam menyelesaikan sebuah masalah.

Hal tersebut diatas sejalan dengan pernyataan Terman seperti yang dikutip oleh Lester (1984), bahwa inteligensi adalah kesanggupan berpikir dalam arti memikirkan hal-hal yang bersifat abstrak. Berbicara tentang berpikir abstrak yang dilakukan para ahli selalu tidak terlepas dari pembicaraan inteligensi. Artinya bahwa berbicara adalah kemampuan berpikir abstrak. Kemampuan berpikir abstrak yang dimiliki manusia adalah tidak sama (unik), meskipun umur adalah sama. Melihat perkembangan kemampuan berpikir abstrak dari segi perkembangan atau pertumbuhan seseorang, Kemampuan berpikir abstrak yang mengarah kepada pelajaran matematika khususnya akan mempengaruhi secara positif terhadap hasil belajar matematika dari anak SMA.

Sibuea (1996), meninjau kemampuan berpikir abstrak dari sisi Diferensial Attitude Tes (DAT), dimana kemampuan berpikir abstrak adalah salah satu komponen dari tes DAT tersebut. Differensial Aptitude Test (DAT) yang pada dasarnya identik dengan tes inteligensi yang menyangkut kemampuan berpikir abstrak, kemampuan verbal, kemampuan ruang dan sebagainya. Anastasi (1990), menjelaskan DAT menyangkut, berpikir verbal, berpikir numerik, berpikir abstrak, kecepatan dan akurasi kesimpulan, berpikir mekanis, hubungan ruang dan penggunaan pengucapan dan bahasa. Dengan demikian tes kemampuan berpikir abstrak dapat menggunakan tes DAT yang telah standart, hanya saja skor untuk pengujian statistik 
hanyalah skor butir kemampuan berpikir abstrak.

Tes kemampuan berpikir abstrak ini mengungkapkan bagaimana sebaiknya seseorang memahami ide-ide yang tidak dinyatakan dengan kata-kata atau angka-angka dan bagaimana baiknya seseorang dapat memikirkan masalah-masalah sekalipun tanpa petunjuk yang berbentuk kata-kata (Sukardi, 2003).

Berdasarkan latar belakang masalah, identifikasi masalah, dan pembatasan masalah, maka rumusan masalah penelitian ini adalah: (1) Apakah hasil belajar matematika siswa yang diajar dengan strategi pembelajaran inkuiri lebih tinggi daripada siswa yang diajar dengan strategi pembelajaran ekspositori ?; (2) Apakah hasil belajar matematika antara siswa yang memiliki kemampuan berpikir abstrak tinggi lebih tinggi dibandingkan dengan siswa yang memiliki kemampuan berpikir abstrak rendah?; dan (3) Apakah terdapat interakasi strategi pembelajaran dan kemampuan berpikir abstrak terhadap hasil belajar matematika?

\section{METODE}

Penelitian ini dilaksanakan di SMA

Negeri 2 Rantau Utara dan SMA Negeri 2

Rantau Selatan Kabupaten Labuhan Batu. Populasi penelitian ini adalah siswa SMA
Negeri 2 Rantau Utara dan SMA Negeri 2 Rantau Selatan Kabupaten Labuhan Batu. Jumlah populasi atau siswa kelas X SMA Negeri 2 Rantau Utara seluruhnya berjumlah 9 kelas dengan total 360 siswa, sedangkan populasi seluruhnya berjumlah 6 kelas dengan total 240 siswa. Sampel dalam penelitian masing-masing 2 kelas dari tiap sekolah yang terdiri dari kelas eksperimen pertama dan kelas eksperimen kedua. Sampel diambil digunakan adalah cluster random sampling atau pengambilan sampel secara acak kelas.

Penelitian ini bersifat eksperimen semu (kuasi eksperimen). Desain ini digunakan karena terdapat variabel bebas yang dimanipulasi dan diprediksi memberikan pengaruh terhadap variabel terikat. Kelompok penelitian ini diberi perlakuan berupa pemberian strategi pembelajaran inkuiri (eksperimen pertama) dan kelompok siswa yang diberikan strategi pembelajaran ekspositori (eksperimen kedua). Dalam pelaksanaan penelitian ini, sebagai upaya untuk mencapai tujuan penelitian maka penelitian ini menggunakan disain faktorial $2 \times 2$. dengan demikian variabel strategi pembelajaran, kemampuan berpikir abstrak siswa, dan hasil belajar matematika dimasukkan ke dalam suatu kerangka tabel data eksprimen penelitian yaitu:

Tabel 1. Rancangan Penelitian Desain Faktorial 2 x 2

\begin{tabular}{ccc}
\hline \multicolumn{1}{c}{ SP } & $\begin{array}{c}\text { INKUIRI } \\
\left(\mathbf{A}_{1}\right)\end{array}$ & $\begin{array}{c}\text { EKSPOSITORI } \\
\left(\mathbf{A}_{2}\right)\end{array}$ \\
\hline KBA & $\mathrm{A}_{1} \mathrm{~B}_{1}$ & $\mathbf{A}_{2} \mathbf{B}_{1}$ \\
\hline KBA Tinggi $\left(\mathbf{B}_{1}\right)$ & $\mathrm{A}_{1} \mathbf{B}_{2}$ & $\mathbf{A}_{2} \mathbf{B}_{2}$ \\
\hline
\end{tabular}

\section{Keterangan:}

$\mathrm{A}_{1}=$ Strategi pembelajaran inkuiri

$\mathrm{A}_{2}=$ Strategi pembelajaran ekspositori

$\mathrm{B}_{1}=$ Kemampuan Berpikir Abstrak Tinggi

$\mathrm{B}_{2}=$ Kemampuan Berpikir Abstrak Rendah

$\mathrm{A}_{1} \mathrm{~B}_{1}=$ Hasil belajar siswa yang diajar dengan strategi pembelajaran inkuiri pada siswa yang memiliki kemampuan berpikir abstrak tinggi.

$\mathrm{A}_{1} \mathrm{~B}_{2}=$ Hasil belajar siswa yang diajar dengan strategi pembelajaran inkuiri pada siswa yang memiliki kemampuan berpikir abstrak rendah
$\mathrm{A}_{2} \mathrm{~B}_{1}=$ Hasil belajar siswa yang diajar dengan strategi pembelajaran ekspositori pada siswa yang memiliki kemampuan berpikir abstrak tinggi

$\mathrm{A}_{2} \mathrm{~B}_{2}=$ Hasil belajar siswa yang diajar dengan strategi pembelajaran ekspositori pada siswa yang memiliki kemampuan berpikir abstrak rendah

$\mathrm{SP}=$ Strategi pembelajaran

$\mathrm{KBA}=$ Kemampuan berpikir abstrak

\section{Teknik Analisa data}

Teknik analisis data penelitian yang digunakan adalah Teknik Analisis Varians (ANAVA) $2 \times 2$ 2. Pengujian Hipotesis 
dilakukan pada taraf signifikan 5\%. Jika dalam pengujian ANAVA ternyata terdapat interaksi strategi pembelajaran dan kemampuan berpikir abstrak terhadap hasil belajar signifikan, maka dilakukan uji lanjut. Uji lanjut yang digunakan adalah uji Tukey. Sebagai Uji Persyaratan analisis dilakukan pengujian normalitas dengan menggunkan uji liliefors. Setelah Uji Normalitas, dilakukan Uji Homogenitas dengan menggunakan Uji F dan Uji Barlett.

Hipotesis yang akan diuji, antara lain:

$\mathrm{H}_{0}: \mu A 1 \leq \mu A 2$

$\mathrm{H}_{\mathrm{a}}: \mu A 1>\mu A 2$

$\mathrm{H}_{0}: \mu B 1 \leq \mu B 2$

$\mathrm{H}_{\mathrm{a}}: \mu B 1>\mu B 2$

$\mathrm{H}_{0}: A \times B=0$

$\mathrm{H}_{0}: A \times B \neq 0$

Keterangan:

A1 = Strategi Pembelajaran Inkuiri

A2 = Strategi Pembelajaran Ekspositori

B1 = Kemampuan Berpikir Abstrak Tinggi
B2 = Kemampuan Berpikir Abstrak Rendah

A $=$ Strategi Pembelajaran

$\mathrm{B}=$ Kemampuan Berpikir Abstrak

$\mathrm{A} \times \mathrm{B}=$ Interaksi antara Strategi Pembelajaran dan Kemampuan Berpikir Abstrak

\section{HASIL PENELITIAN \\ Pengujian Hipotesis}

Pengujian hipotesis dilakukan dengan menggunakan teknik analisis varians (anava) dua jalur dengan faktorial $2 \times 2$, dengan ketentuan:

- Jika nilai $F_{\text {hitung }}<F_{\text {tabek }}$ pada $\alpha=0,05$ maka $\mathrm{H}_{\mathrm{a}}$ ditolak dan $\mathrm{H}_{0}$ diterima.

- Jika nilai $F_{\text {hitung }}>F_{\text {tabek }}$ pada $\alpha=0,05$ maka $\mathrm{H}_{\mathrm{a}}$ diterima dan $\mathrm{H}_{0}$ ditolak.

Perbandingan data-data hasil belajar matematika siswa berdasarkan temuan penelitian dirangkum pada Tabel 2.

Tabel 2. Perbandingan Hasil Belajar Matematika Siswa Berdasarkan Strategi Pembelajaran Inkuiri dan Kemampuan Berpikir Abstrak

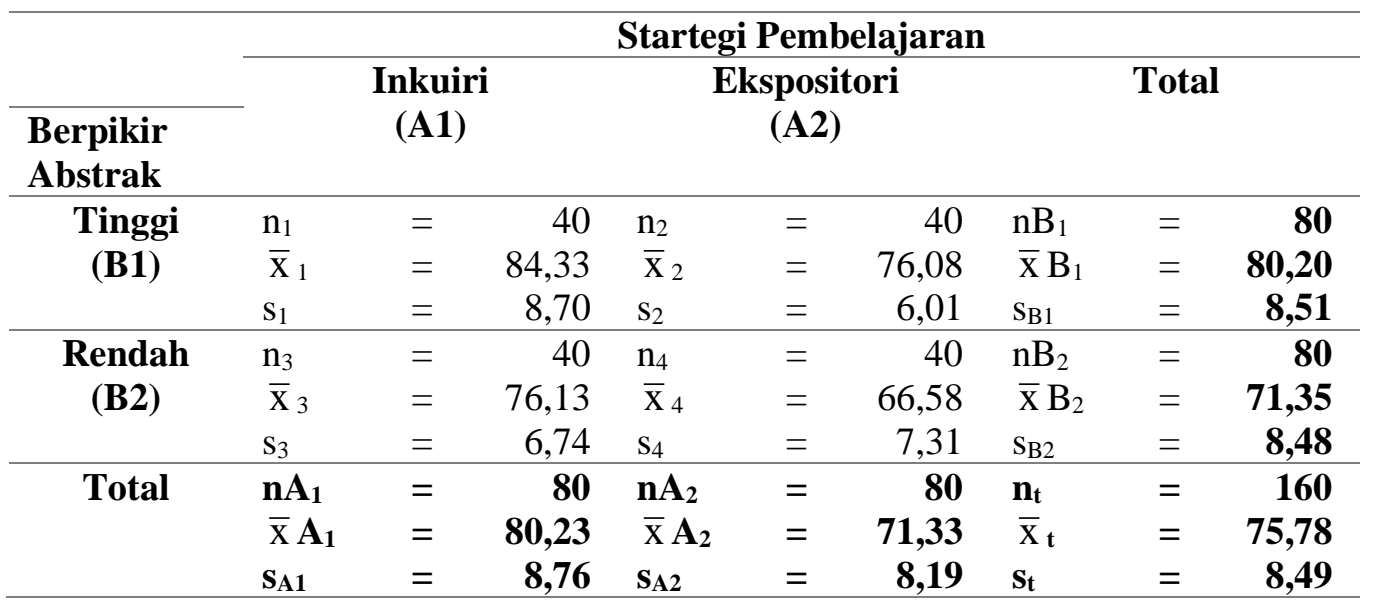

Hasil perhitungan analisis varians dua jalur pada Lampiran 19, secara ringkas dirangkum pada Tabel 3.

Tabel 3. Rangkuman Hasil Pengujian Analisis Varians Dua Jalur

\begin{tabular}{lcrrrr}
\hline Sumber Varians & dk & JK & $\mathbf{R K}=\mathbf{J K} / \mathbf{d k}$ & $\mathbf{F}_{\text {hitung }}$ & $\mathbf{F}_{\mathbf{t}(\boldsymbol{\alpha}=\mathbf{0 , 0 5})}$ \\
& & & & & \\
\hline Antar Kolom (A) & 1 & 3168,40 & 3168,40 & 60,162 & $\mathbf{3 , 9 1}$ \\
Antar Baris (B) & 1 & 3132,90 & 3132,90 & 59,488 & $\mathbf{3 , 9 1}$ \\
Interaksi (AB) & 1 & 16,90 & 16,90 & 0,321 & $\mathbf{3 , 9 1}$ \\
\hline Dalam & 156 & 8215,70 & 52,665 & & \\
\hline Total Direduksi & $\mathbf{1 5 9}$ & $\mathbf{1 4 5 3 3 , 9 0}$ & - & & \\
\hline
\end{tabular}


Perbedaan Hasil Belajar Siswa yang Dibelajarkan dengan Strategi Pembelajaran Inkuiri dengan Strategi Pembelajaran Ekspositori adalah:

Adapun hipotesis statistik, yang diuji

\section{$\mathrm{H}_{\mathrm{o}}: \mu \mathrm{A}_{1} \leq \mu \mathrm{A}_{2}$}

$\mathrm{H}_{\mathrm{a}}: \mu \mathrm{A}_{1}>\mu \mathrm{A}_{2}$

Hasil temuan penelitian diperoleh ratarata hasil belajar matematika kelompok siswa yang diajarkan dengan strategi pembelajaran inkuiri sebesar 80,23 dan kelompok siswa yang diajarkan dengan strategi pembelajaran ekspositori diperoleh rata-rata sebesar 71,33.

Berdasarkan hasil pada Tabel 3, diperoleh nilai $F_{\text {hitung }}$ sebesar 60,162. Pada taraf signifikansi $\alpha=0,05$ diperoleh $\mathrm{F}_{0,05(1,56)}=3,91$. Karena $F_{\text {hitung }}>F_{\text {tabel }}$ yaitu 60,162 > 3,91 maka terima $\mathrm{H}_{\mathrm{a}}$ sehingga disimpulkan hasil belajar matematika siswa yang diajar dengan strategi pembelajaran inkuiri lebih tinggi dibandingkan hasil belajar matematika siswa yang diajar dengan strategi pembelajaran ekspositori.

Perbedaan Hasil Belajar Siswa yang Memiliki Kemampuan Berpikir Abstrak Tinggi dengan Siswa yang Memiliki Kemampuan Berpikir Abstrak Rendah adalah:

Adapun hipotesis statistik, yang diuji

$\mathrm{H}_{\mathrm{o}}: \mu \mathrm{B}_{1} \leq \mu \mathrm{B}_{2}$

$\mathrm{H}_{\mathrm{a}}: \mu \mathrm{B}_{1}>\mu \mathrm{B}_{2}$

Hasil temuan penelitian diperoleh ratarata hasil belajar matematika untuk kelompok siswa yang memiliki kemampuan berpikir abstrak tinggi sebesar 80,20 dan kelompok siswa yang memiliki kemampuan berpikir abstrak rendah diperoleh rata-rata sebesar 71,35 .

Berdasarkan hasil pada Tabel 3, diperoleh nilai $\mathrm{F}_{\text {hitung }}$ sebesar 59,488. Pada taraf signifikansi $\alpha=0,05$ diperoleh $\mathrm{F}_{0,05(1,56)}=3,91$. Karena $F_{\text {hitung }}>F_{\text {tabel }}$ yaitu 59,488 $>3,91$ maka terima $\mathrm{H}_{\mathrm{a}}$ sehingga disimpulkan bahwa hasil belajar matematika siswa yang memiliki kemampuan berpikir abstrak tinggi lebih tinggi dibandingkan dengan hasil belajar matematika siswa yang memiliki kemampuan berpikir abstrak rendah.

Interaksi Antara Strategi Pembelajaran dan Kemampuan Berpikir Abstrak Siswa Terhadap Hasil Belajar Matematika

Adapun hipotesis statistik, yang diuji
$\mathrm{H}_{\mathrm{o}}: \mu \mathrm{A}><\mu \mathrm{B}=0$

$\mathrm{H}_{\mathrm{a}}: \mu \mathrm{A}>\langle\mu \mathrm{B} \neq 0$

Hasil temuan penelitian diperoleh ratarata hasil belajar matematika untuk kelompok siswa yang diajarkan dengan strategi pembelajaran inkuiri dengan kemampuan berpikir abstrak tinggi sebesar 84,33; kelompok siswa yang diajarkan dengan strategi pembelajaran inkuiri dengan kemampuan berpikir abstrak rendah diperoleh rata-rata sebesar 76,13; kelompok siswa yang diajarkan dengan strategi pembelajaran ekspositori dengan kemampuan berpikir abstrak tinggi diperoleh rata-rata sebesar 76,08; dan kelompok siswa yang diajarkan dengan strategi pembelajaran ekspositori dengan kemampuan berpikir abstrak rendah diperoleh rata-rata sebesar 66,58.

Selanjutnya berdasarkan hasil pada Tabel 4.13, diperoleh nilai $\mathrm{F}_{\text {hitung }}$ sebesar 0,321. Pada taraf signifikansi $\alpha=0,05$ diperoleh $\mathrm{F}_{0,05}$ $(1,56)=3,91$. Karena $F_{\text {hitung }}<F_{\text {tabel }}$ yaitu $0,321<$ 3,91 maka terima $\mathrm{H}_{0}$ atau tolak $\mathrm{H}_{a}$ sehingga disimpulkan tidak terdapat interaksi antara strategi pembelajaran dan kemampuan berpikir abstrak tehadap hasil belajar matematika siswa.

Dari hasil pengujian yang ketiga menyatakan tidak terdapat interaksi antara strategi pembelajaran dan kemampuan berpikir abstrak siswa terhadap hasil belajar matematika siswa, sehingga tidak perlu dilakukan pengujian lanjutan untuk mengetahui rata-rata nilai mana yang memberi pengaruh yang lebih baik terhadap hasil belajar matematika siswa.

Lebih jelasnya tidak adanya interaksi antara strategi pembelajaran dan kemampuan berpikir abstrak terhadap hasil belajar matematika siswa, dapat divisualisasikan pada grafik berikut.

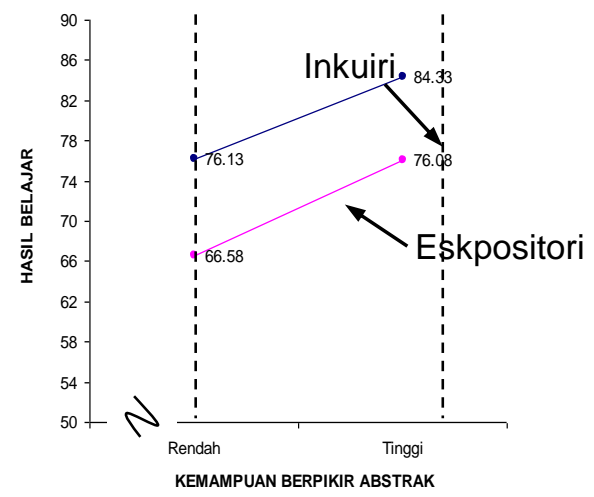

Gambar 1. Pola Interaksi Antara Strategi Pembelajaran dan Kemampuan Berpikir Abstrak Terhadap Hasil Belajar Matematika Siswa adalah: 


\section{PEMBAHASAN}

\section{Perbedaan Hasil Belajar Siswa yang Diajarkan dengan Strategi Pembelajaran Inkuiri dengan Pembelajaran Ekspositori}

Hasil temuan penelitian, diperoleh ratarata nilai hasil belajar matematika siswa yang diajarkan dengan strategi pembelajaran inkuiri sebesar 80,23 sedangkan rata-rata nilai hasil belajar matematika siswa yang diajarkan dengan strategi pembelajaran ekspositori sebesar 71,33. Hasil pengujain hipotesis diperoleh nilai $F_{\text {hitung }}>F_{\text {tabel }}$ yaitu 60,162 $>3,91$ sehingga hipotesis pertama yang diajukan diterima dan disimpulkan bahwa hasil belajar matematika siswa yang diajar dengan strategi pembelajaran inkuiri lebih tinggi daripada hasil belajar siswa yang diajar dengan strategi pembelajaran ekspositori.

Kesimpulan ini juga diperkuat dengan pendapat Sutrisno (2006), menyimpulkan bahwa model latihan inkuiri dengan gaya berpikir sekunsial abstrak lebih tinggi dibandingkan dengan model latihan konvensional. Sebaliknya, siswa yang memiliki gaya berpikir sekuensial konkrit dibelajarkan dengan model latihan inkuiri lebih tinggi dibandingkan dengan model konvensional. Lebih lanjut hasil penelitian. Selanjutnya menurut Sanjaya (2009), strategi pembelajaran inkuiri dapat memberikan ruang kepada siswa untuk belajar sesuai dengan gaya belajar siswa, sesuai dengan perkembangan psikologi belajar modern yang menganggap belajar adalah proses perubahan tingkah laku berkat adanya pengalaman dan strategi ini dapat melayani kebutuhan siswa yang memiliki kemampuan di atas rata-rata. Artinya, siswa yang memiliki kemampuan belajar bagus tidak akan terhambat oleh siswa yang lemah dalam belajar.

Selama proses pembelajaran siswa yang diajarkan dengan strategi pembelajaran inkuiri tampak lebih aktif mulai dari memahami soal, merumusakan masalah (misalnya soal: $4 \mathrm{x}^{2}+$ $2 \mathrm{x}+1=0$, berapkah nilai $a^{2}+b^{2}+\mathrm{c}^{2}$, siswa dituntu untuk dapat merumuskan masalah apaapa yang diketahui dan apa yang ditanyakan pada soal), merumuskan hipotesis (siswa dituntut untuk dapat menentukan model matematika yang tepat, misalnya: $4 \mathrm{x}^{2}+2 \mathrm{x}+1$ $=0$ dalam model matematika $a \mathrm{x}^{2}+b \mathrm{x}+\mathrm{c}=0$ maka $a=4 ; b=2$ dan $c=1$ ), menemukan jawaban soal dengan aktif berdiskusi dalam kelompok untuk membuat kesimpulan yang benar dari masalah atau soal-soal yang diberikan guru (siswa menemukan jawaban: $a^{2}$ $+b^{2}+c^{2}=4^{2}+2^{2}+1^{2}=16+4+1=21$ dan membuat kesimpulan: $\left.a^{2}+b^{2}+c^{2}=21\right)$. Tugastugas yang diberikan dapat diselesaikan dengan baik dan tepat waktu. Sementara siswa yang diajarkan dengan strategi pembelajaran ekspositori cenderung diam dan pasif mendengarkan penjelasan guru, kurang semangat dalam belajar, dan hanya beberapa siswa yang aktif mengajukan pertanyaan, siswa juga cenderung hanya membuat catatan dari apa yang dijelaskan guru di depan kelas. Tugastugas yang diberikan juga kurang dapat diselesaikan dengan baik dan tepat waktu.

\section{Perbedaan Hasil Belajar Siswa yang Memiliki Kemampuan Berpikir Abstrak yang Tinggi dengan Siswa yang Memiliki Kemampuan Berpikir Abstrak Rendah}

Selanjutnya hasil tabulasi dan temuan penelitian diperoleh rata-rata hasil belajar matematika siswa yang memiliki kemampuan berpikir abstrak yang tinggi (baik yang diajar dengan strategi pembelajaran inkuiri maupun yang diajar dengan strategi pembelajaran ekspositori) sebesar 80,20. Sedangkan rata-rata hasil belajar matematika siswa yang memiliki kemampuan berpikir abstrak rendah (baik yang diajar dengan strategi pembelajaran inkuiri maupun yang diajar dengan strategi pembelajaran ekspositori) sebesar 71,35. Hasil pengujain hipotesis diperoleh nilai $\mathrm{F}_{\text {hitung }}>\mathrm{F}_{\text {tabel }}$ yaitu 59,488 $<3,91$ sehingga hipotesis kedua yang diajukan diterima dan disimpulkan bahwa hasil belajar matematika siswa yang memiliki kemampuan berpikir abstrak tinggi lebih tinggi dibandingkan dengan siswa yang memiliki kemampuan berpikir abstrak rendah.

Kesimpulan di atas juga diperkuat dengan hasil penelitian Sibarani (2007) yang mengemukakan bahwa kemampuan berpikir abstrak mempengaruhi hasil belajar siswa dengan strategi pemberian umpan balik dan ekspositori pada pelajaran fisika. Selama pembelajaran siswa yang memiliki kemampuan berpikir abstrak tinggi pada kelas yang diajarkan dengan strategi pembelajaran inkuiri cenderung lebih konsentrasi, lebih mudah memahami soal-soal yang diberikan sehingga dapat merumuskan masalah atau hipotesis untuk menjawab soal-soal yang ada. Siswa yang memiliki kemampuan berpikir abstrak tinggi juga lebih percaya diri dan lebih kreatif dalam memecahkan masalah atau soal-soal yang diberikan guru. Demikian halnya pada kelas yang dibelajarkan dengan strategi 
pembelajaran ekspositori, siswa yang memiliki kemampuan berpikir abstrak tinggi cenderung lebih kreatif yang ditunjukkan dari keingintahuan siswa melalui pertanyaanpertanyaan yang dikemukakan, dan lebih percaya diri menjawab pertanyaan atau soal latihan yang diberikan guru.

Berdasarkan hasil analisis jawaban siswa pada tes yang diberikan juga menunjukkan bahwa kelompok siswa yang memiliki kemampuan berpikir abstrak tinggi baik yang diajarkan dengan strategi pembelajaran inkuiri maupun strategi pembelajaran ekspositori lebih mampu menyelesaikan soal-soal terutama pada aspek taksonomi Bloom C3, C4, C5 dan C6 dibandingkan kelompok siswa yang memiliki kemampuan berpikir abstrak rendah baik yang diajarkan dengan strategi pembelajaran inkuiri maupun ekspositori.

Interaksi Antara Strategi Pembelajaran dan Kemampuan Berpikir Abstrak Siswa Terhadap Hasil Belajar Matematika

Hasil pengelompokkan data diperoleh hasil belajar matematika untuk kelompok siswa yang diajarkan dengan strategi pembelajaran inkuiri dengan kemampuan berpikir abstrak tinggi rata-rata sebesar 84,33; kelompok siswa yang diajarkan strategi pembelajaran inkuiri dengan kemampuan berpikir abstrak rendah diperoleh rata-rata hasil belajar sebesar 76,13; kelompok siswa yang diajarkan strategi pembelajaran ekspositori dengan kemampuan berpikir abstrak tinggi diperoleh rata-rata hasil belajar sebesar 76,08; dan kelompok siswa yang diajarkan strategi pembelajaran ekspositori dengan kemampuan berpikir abstrak rendah diperoleh rata-rata hasil belajar matematika sebesar 66,58.

Hasil temuan penelitian menunjukkan bahwa rata-rata hasil belajar matematika kelompok siswa yang memiliki kemampuan berpikir abstrak tinggi diajarkan dengan strategi pembelajaran inkuiri (84,33), lebih tinggi dibandingkan kelompok siswa lainnya yaitu kelompok siswa yang memiliki kemampuan berpikir abstrak rendah diajarkan dengan strategi pembelajaran inkuiri $(76,13)$. Begitu juga kelompok siswa yang memiliki kemampuan berpikir abstrak tinggi diajarkan strategi pembelajaran ekspositori $(76,08)$ lebih tinggi dibandingkan kelompok siswa yang memiliki kemampuan berpikir abstrak rendah diajarkan strategi pembelajaran ekspositori $(66,58)$.

Hasil penelitian ini juga sekaligus mendukung penelitian Santoso (2007), yang menyimpulkan tidak ada pengaruh interaksi antara pendekatan inquiry dengan cooperative learning, antara pendekatan inquiry dengan kemampuan akademik siswa, antara cooperative learning dengan kemampuan akademik siswa, dan antara pendekatan inquiry dengan cooperative learning dan kemampuan akademik siswa terhadap kemampuan berpikir kritis.

Penggunaan strategi pembelajaran merupakan salah satu bentuk usaha guru dalam mencapai tujuan belajar yang diharapkan yaitu agar siswa memperoleh hasil belajar yang lebih baik, tetapi jika siswa sendiri tidak memiliki kemampuan berpikir abstrak yang tinggi maka siswa tersebut akan sulit memperoleh hasil yang lebih baik terutama dalam memahami materi yang disampaikan guru dan mengerjakan soalsoal matematika yang diberikan guru. Jadi, pada dasarnya kemampuan berpikir abstrak seseorang sangat menentukan keberhasilannya dalam belajar. Hasil penelitian Sibarani (2007), menyimpulkan bahwa kemampuan berpikir abstrak mempengaruhi hasil belajar siswa dengan strategi pemberian umpan balik dan ekspositori pada pelajaran fisika. Artinya keberhasilan siswa dalam belajar dipengaruhi oleh kemampuan berpikir abstrak siswa meskipun siswa diajarkan dengan strategi pembelajaran yang berbeda. Lebih lanjut Suhendro (2006), menjelaskan bahwa dalam berpikir abstrak tentu saja berpengaruh terhadap prestasi belajar matematika, bila siswa sudah mencapai taraf berpikir abstrak, maka secara tidak langsung mempengaruhi cara belajar hingga prestasinya, namun belum tentu dengan berpikir abstrak setiap siswa mampu menyelesaikan permasalahannya, tidak semua masalah harus diselesaikan dengan cara berpikir abstrak.

Menurut Erman (2009), untuk meningkat kemampuan berpikir abstrak siswa diperlukan waktu intervensi yang sistematis dan berkelanjutan dalam waktu yang cukup lama. Pendapat Erman tersebut memberi indikasi bahwa untuk meningkatkan kemampuan berpikir abstrak siswa diperlukan pembiasaan atau latihan secara sistematis dan berkelanjutan dengan waktu yang cukup lama. Pada penelitian yang telah dilakukan, proses pembelajaran hanya dilakukan selama 8 kali pertemuan atau 
selama 16 kali 45 menit. Waktu ini masih dirasa kurang cukup untuk dapat membiasakan dan melatih siswa yang memiliki kemampuan berpikir abstrak rendah agar dapat meningkatkan kemampuan berpikir abstraknya. Dengan demikian, kurangnya waktu yang digunakan juga merupakan salah satu faktor sehingga tidak ada interaksi antara strategi pembelajaran inkuiri dan kemampuan berpikir abstrak siswa terhadap hasil belajar matematika siswa.

\section{PENUTUP}

Hasil-hasil temuan penelitian dan analisis yang telah dilakukan, diperoleh beberapa simpulan, antara lain:

1. Hasil belajar matematika siswa yang diajar dengan strategi pembelajaran inkuiri (ratarata 80,23) lebih tinggi dibandingkan hasil belajar siswa yang diajar dengan strategi pembelajaran ekspositori (rata-rata 71,33). Dengan demikian, dalam mengajarkan matematika diharapkan guru dapat menggunakan strategi pembelajaran inkuiri agar siswa dapat memperoleh hasil belajar yang lebih baik.

2. Hasil belajar matematika siswa yang memiliki kemampuan berpikir abstrak tinggi (rata-rata 80,20) lebih tinggi dibandingkan dengan siswa yang memiliki kemampuan berpikir abstrak rendah (ratarata 71,35). Oleh karena itu, dalam mengajarkan matematika hendaknya guru berusaha menumbuhkembangkan kemampuan berpikir abstrak siswa dalam memahami ide-ide yang tidak dinyatakan dengan kata-kata atau angka-angka dalam matematika dan bagaimana baiknya seseorang dapat memikirkan masalahmasalah sekalipun tanpa petunjuk yang berbentuk kata-kata, sehingga siswa mampu memecahkan berbagai permasalahan belajar yang dialaminya dan pada akhirnya dapat meningkatkan hasil belajarnya.

3. Tidak terdapat interaksi antara strategi pembelajaran dan kemampuan berpikir abstrak tehadap hasil belajar matematika siswa. Hal ini memberi makna bahwa siswa yang dibelajarkan dengan strategi pembelajaran inkuiri meskipun memiliki kemampuan berpikir tinggi ataupun rendah tidak berarti akan lebih baik dibandingkan siswa yang dibelajarkan dengan strategi pembelajaran ekspositori. Siswa yang memiliki kemampuan berpikir abstrak tinggi jika diajarkan dengan strategi pembelajaran inkuiri maupun dengan pembelajaran ekspositori akan memperoleh nilai yang lebih tinggi jika dibandingkan siswa yang memiliki kemampuan berpikir abstrak rendah.

\section{DAFTAR PUSTAKA}

Amri, S \& Ahmadi I, K (2010). Proses Pembelajaran Kreatif dan Inovatif dalam Kelas. Jakarta: Prestasi Pustakaraya.

Anastasi, A \& Urbina, S. (1997). Tes Psikologi. Edisi Bahasa Indonesia. Jakarta: Prenhallindo.

Anderson, L.W, et al. (2001). A Taxonomy for Learning Teaching and Assesing; A Revision of Blooms Taxonomi for Educational Objectives. New York. Longan Inc.

Depdiknas, (2004). Panduan KBK 2004, BNSP: Jakarta.

Dick, W. \& Carey, L. (2005). The systemathics of design instructional. Florida: Harper Callens Publisher.

Erman. (2009). Penerapan Strategi Intervensi dalam Pembelajaran IPA Untuk Memacu Perkembangan Kemampuan Berpikir Siswa Pada Usia Peralihan di SD, Jurnal Pendidikan Dasar, 10 (1), 68-79.

Gagne, R.M. \& Briggs, L.J. (1979). Principles of Instructional Design. New York: Holt Rinehart and Winston.

Gulo, W (2008). Strategi Belajar Mengajar. Jakarta: Grasindo

Hamalik, O. (2001). Perencanaan Pengajaran Berdasarkan Pendekatan Sistem. Jakarta: Bumi Aksara.

Lester D.C. (1984), Psikologi Pendidikan. Surabaya: Bina Ilmu.

Lie, A. (2004). Cooperative learning. Jakarta: Grasindo.

Majid, A. (2005). Perencanaan Pembelajaran. Bandung: Remaja Rosdakarya.

Masykur, M \& Fathani, H, A. (2007). Mathematical Intelligence ( Cara Cerdas Melatih Otak dan Menanggulangi Kesulitan Belajar). Yogyakarta: ARRUZZ Media.

Nasution, S. (1995). Kurikulum dan pengajaran. Jakarta: Bumi Aksara.

Nugroho, W. (2004). Penerapan Manajemen Pengetahuan dalam Peningkatan Kualitas Pembelajaran. http://widyo.staff.gunadarma.ac.id/Public ations/ files/625/KM-2.doc. 
Patmonodewo, S. (2001). Psikologi Perkembangan Pribadi. Jakarta: UI Press.

Reigeluth, C.M (1983). Instructional Design Teories and Models: An Overviews of Their Current Status. Hillsdale, NJ: Lawrence Erlbaum Associates.

Roestiyah, R. (1995). Didaktik Metodik. Jakarta: Bumi Aksara.

Sagala, S. (2009). Konsep Dan Makna Pembelajaran. Bandung: Alfabeta.

Sanjaya, W. (2008). Strategi Pembelajaran. Jakarta: Kencana Prenada Media Group.

Santoso, H. (2007). Pengaruh Cooperative Learning Dipandu Inquiry Terhadap Kemampuan Berpikir Kritis Siswa SMA Berkemampuan Atas dan Bawah di Kota Metro.

http://www.ummetro.ac.id/file_jurnal/7. Handoko UM Metro.pdf.

Sibarani, S. (2007). Pengaruh Pemeberian Umpan Balik dan Kemampuan Berpikir Abstrak Terhadap Hasil Belajar Fisiska Siswa kelas II SMP Negeri 16 Medan. Tesis. Program Pascasarjana. Universitas Negeri Medan.

Sibuea, A.M. (1996). Hubungan Antara Kemampuan Mengingat dan Abstrak dengan Prestasi Belajar Teknik

Komputer. Laporan Penelitian. IKIP Medan.

Slameto. (1995). Belajar dan Faktor-Faktor yang Mempengaruhinya. Jakarta: Rineka Cipta.

Slavin, R.E. (1995). Cooperatif Learning Theory Research and Practice. second Edition. Massachustts: Allyn and Bacon Publishers.

Suhendro. (2006). Dampak Pola Fikir Abstrak Terhadap Prestasi Siswa Matematik. Likithapradnya, Vol. 1 April 2006.

Sukardi, K.D,. (2003). Analisis Tes Psikologis. Jakarta: Rineka Cipta.

Suriasumantri, J.S. (1995). Filsafat Ilmu. Jakarta: Sinar Harapan.

Sutrisno. (2006). Pengaruh Model Pembelajaran Latihan Inkuiri dan Gaya Berpikir Terhadap Hasil Belajar Kimia Siswa Madrasah Aliyah. Tesis. Pascasarjana Universitas Negeri Medan.

Suyanti, R.D. (2010). Strategi Pembelajaran Kimia. Yogyakarta: Graha Ilmu.

Uno, H.B. (2009). Model Pembelajaran Menciptakan Proses Belajar Mengajar yang Kreatif dan Efektif, Jakarta: Bumi Aksara. 